\title{
Body condition alters glutathione and nuclear factor erythroid 2-like 2 (NFE2L2)-related antioxidant network abundance in subcutaneous adipose tissue of periparturient Holstein cows
}

\author{
Y. Liang, ${ }^{1}$ A. S. Alharthi, ${ }^{1}$ R. Bucktrout, ${ }^{1}$ A. A. Elolimy,,${ }^{2,3,4}$ V. Lopreiato, ${ }^{5}$ I. Martinez-Cortés, ${ }^{1,6}$ C. Xu, ${ }^{7}$ \\ C. Fernandez, ${ }^{8}$ E. Trevisi, ${ }^{5}$ and J. J. Loor ${ }^{1 *}$ \\ ${ }^{1}$ Department of Animal Sciences and Division of Nutritional Sciences, University of Illinois, Urbana 61801 \\ ${ }^{2}$ Department of Pediatrics, University of Arkansas for Medical Sciences, Little Rock 72205 \\ ${ }^{3}$ Arkansas Children's Nutrition Center, Little Rock 72205 \\ ${ }^{4}$ Department of Animal Production, National Research Centre, Giza 12611, Egypt \\ ${ }^{5}$ Department of Animal Sciences, Food and Nutrition, Faculty of Agriculture, Food and Environmental Science, \\ Università Cattolica del Sacro Cuore, 29122 Piacenza, Italy \\ ${ }^{6}$ Agricultural and Animal Production Department, UAM-Xochimilco, Mexico City 04960, Mexico \\ ${ }^{7}$ College of Animal Science and Veterinary Medicine, Heilongjiang Bayi Agricultural University, Xinyang Rd. 5, Daqing, 163319, Heilongjiang, \\ China \\ ${ }^{8}$ Animal Science Department, Universitàt Politècnica de Valencia, 46022 Valencia, Spain
}

\begin{abstract}
Dairy cows with high body condition score (BCS) in late prepartum are more susceptible to oxidative stress (OS). Nuclear factor erythroid 2-like 2 (NFE2L2) is a major antioxidant transcription factor. We investigated the effect of precalving BCS on blood biomarkers associated with OS, inflammation, and liver function, along with mRNA and protein abundance of targets related to NFE2L2 and glutathione (GSH) metabolism in s.c. adipose tissue (SAT) of periparturient dairy cows. Twenty-two multiparous Holstein cows were retrospectively classified into a high BCS (HBCS; $\mathrm{n}=$ 11 , BCS $\geq 3.5$ ) or normal BCS (NBCS; $\mathrm{n}=11$, BCS $\leq 3.17$ ) on d 28 before parturition. Cows were fed a corn silage- and wheat straw-based total mixed ration during late prepartum, and a corn silage- and alfalfa haybased total mixed ration postpartum. Blood samples obtained at $-10,7,15$, and $30 \mathrm{~d}$ relative to parturition were used for analyses of biomarkers associated with inflammation, including albumin, ceruloplasmin, haptoglobin, and myeloperoxidase, as well as OS, including ferric reducing ability of plasma (FRAP), reactive oxygen species (ROS), and $\beta$-carotene. Adipose biopsies harvested at $-15,7$, and $30 \mathrm{~d}$ relative to parturition were analyzed for mRNA (real-time quantitative PCR) and protein abundance (Western blotting) of targets associated with the antioxidant transcription regula-
\end{abstract}

Received October 29, 2019.

Accepted February 29, 2020.

*Corresponding author: jloor@illinois.edu tor nuclear factor, NFE2L2, and GSH metabolism pathway. In addition, concentrations of GSH, ROS and malondialdehyde were measured. High BCS cows had lower prepartum dry matter intake expressed as a percentage of body weight along with greater BCS loss between -4 and 4 wk relative to parturition. Plasma concentrations of ROS and FRAP increased after parturition regardless of treatment. Compared with NBCS, HBCS cows had greater concentrations of FRAP at d 7 postpartum, which coincided with peak values in those cows. In addition, NBCS cows experienced a marked decrease in plasma ROS after d 7 postpartum, while HBCS cows maintained a constant concentration by d 30 postpartum. Overall, ROS concentrations in SAT were greater in HBCS cows. However, overall mRNA abundance of NFE2L2 was lower and cullin 3 (CUL3), a negative regulator of NFE2L2, was greater in HBCS cows. Although HBCS cows had greater overall total protein abundance of NFE2L2 in SAT, ratio of phosphorylated NFE2L2 to total NFE2L2 was lower, suggesting a decrease in the activity of this antioxidant system. Overall, mRNA abundance of the GSH metabolism-related genes glutathione reductase (GSR), glutathione peroxidase 1 (GPX1), and transaldolase 1 (TALDO1), along with protein abundance of glutathione S-transferase mu 1 (GSTM1), were greater in HBCS cows. Data suggest that HBCS cows might experience greater systemic OS after parturition, while increased abundance of mRNA and protein components of the GSH metabolism pathway in SAT might help alleviate tissue oxidant status. Data underscored the importance of antioxidant mechanisms at the tissue level. Thus, targeting these pathways in SAT during the peripar- 
turient period via nutrition might help control tissue remodeling while allowing optimal performance.

Key words: body condition score, oxidative stress, NFE2L2, adipose

\section{INTRODUCTION}

Body condition score is used to evaluate the degree of apparent adiposity in dairy cows (Roche et al., 2013). A high body condition score $(\mathrm{BCS} \geq 3.5)$ at calving is negatively associated with early-lactation DMI and milk yield, and is positively related to the incidence of periparturient metabolic disorders (Roche et al., 2009). For instance, cows calving at a high BCS are more likely to experience fatty liver, subclinical ketosis, and chronic oxidative stress (OS) during the transition period (Reid et al., 1986; Bernabucci et al., 2005; Loor et al., 2013a). Despite extensive research on the use of BCS as a management tool and its association with important physiological aspects such as lipid metabolism, insulin resistance and inflammation (De Koster et al., 2015; Depreester et al., 2018; Newman et al., 2019), molecular mechanisms of OS associated with BCS in adipose tissue are not well-known.

Nuclear factor erythroid 2-like 2 (NFE2L2), considered a master antioxidant transcription factor, plays a critical role against OS damage via regulating a wide range of antioxidant response-dependent genes in mammals (Ma, 2013). Changes in transcription of NFE2L2 in the liver during the transition period are thought to play a role in regulating tissue antioxidant response (Gessner et al., 2013). More recent in vitro and in vivo data indicate that activation of NFE2L2 (and its target genes) could serve as a mechanism to maintain oxidant status in the mammary gland (Han et al., 2018a,b; Ma et al., 2018). Greater protein abundance of targets associated with the NFE2L2 pathway, coupled with elevated plasma malondialdehyde, was reported in subcutaneous adipose tissue (SAT) in cows calving during the summer compared with winter, suggesting this pathway also might be important in coping with OS in SAT (Zachut et al., 2017). Indeed, an essential role of the NFE2L2 pathway in the antioxidant response in bovine adipose tissue was underscored by a recent in vitro study demonstrating that mild OS led to greater abundance of NFE2L2 at both transcription and translation levels, while severe OS resulted in lower abundance (Sun et al., 2019).

Glutathione (GSH) is a well-known antioxidant in cells, and contributes to eliminating $\mathrm{H}_{2} \mathrm{O}_{2}$ within the cytosol, hence, preventing oxidative damage and regulating the thiol-redox status in tissues (Aquilano et al., 2014). A previous study from our group revealed that enhanced post-ruminal supply of Met, the source of thiol-groups, led to alleviated OS, along with greater mRNA abundance of glutamate-cysteine ligase modifier subunit, glutathione reductase $(G S R)$, and glutathione peroxidase 1 (GPX1). The greater activity of various GSH-related antioxidant enzymes in peripartal dairy cow SAT underscored the importance of GSH metabolism and its responsiveness to changes in physiologic state (Batistel et al., 2017; Liang et al., 2019).

Our general hypothesis was that normal prepartal BCS leads to the activation of the NFE2L2 pathways, ensuing greater GSH synthesis in SAT. The main objective of this study was to investigate changes in mRNA and protein abundance of major components related to the NFE2L2 and GSH pathways in SAT, along with plasma and tissue biomarkers of OS in peripartal cows calving at a high or low BCS.

\section{MATERIALS AND METHODS}

\section{Experiment Design}

All procedures were conducted under protocols approved by the University of Illinois Institutional Animal Care and Use Committee (Urbana; protocol \#17168). Body condition score was monitored weekly by 3 individuals from $-4 \mathrm{wk}$ to $4 \mathrm{wk}$ relative to expected parturition date, and mean values were used for classifying cows in the current study. Twenty-two clinically healthy multiparous Holstein cows were retrospectively classified into 2 groups: high BCS (HBCS; $3.75 \pm 0.25$, 3.5-4.0; mean $\pm \mathrm{SD} ; \mathrm{n}=11$ ) and normal BCS (NBCS; $3.07 \pm 0.07,3.0-3.17$; mean $\pm \mathrm{SD} ; \mathrm{n}=11$ ), at $\mathrm{d} 28$ before parturition based on a 5-point scale (Edmonson et al., 1989). The average (mean $\pm \mathrm{SD}$ ) BW at $-4 \mathrm{wk}$ relative to parturition was $896 \pm 51 \mathrm{~kg}$ and $786 \pm 48 \mathrm{~kg}$ in HBCS and NBCS, respectively. The average for parity (mean \pm SD) was $3.5 \pm 1.6$ in HBCS cows and $3.0 \pm$ 1.1 for NBCS. Cows were fed a corn silage- and wheat straw-based TMR during late prepartum period and a corn silage- and alfalfa hay-based TMR after parturition (Table 1). Cows were fed once daily $(0600 \mathrm{~h})$ with ad libitum access to the diet. Dry cows were housed in a freestall barn with an individual Calan gate feeding system (American Calan, Northwood, NH). After calving, cows were housed in a tie-stall barn and milked 3 times daily at approximately 0600, 1400, and $2200 \mathrm{~h}$. Milk production and feed refusals were recorded daily for each cow. Diets were formulated to meet predicted requirements for dairy cows according to NRC (2001).

\section{Feed Sample Collection}

Individual ingredients and TMR samples were collected once a week to determine the DM and used 
to adjust the DM of the TMR accordingly. Weekly samples of ingredients and TMR were frozen at $-20^{\circ} \mathrm{C}$ and pooled monthly for nutrient composition analysis, as described previously by Batistel et al. (2017). The ingredients and nutrient compositions of the diets are reported in Table 1.

\section{Blood Collection and Analyses}

Blood was obtained from the coccygeal vein before morning feeding at $-10( \pm 1 \mathrm{~d}), 7,15$, and $30 \mathrm{~d}$ relative to parturition. Samples were collected in Vacutainer tubes containing lithium heparin (BD Vacutainer, Becton, Dickinson and Co., Franklin Lakes, NJ) and were immediately placed on ice. Plasma was harvested by centrifugation at $2,000 \times g$ for $15 \mathrm{~min}$ at $4^{\circ} \mathrm{C}$, and aliquots stored at $-80^{\circ} \mathrm{C}$ until further analysis. Activities of aspartate aminotransferase (AST), $\gamma$-glutamyl transpeptidase (GGT), alkaline phosphatase, myeloperoxidase and paraoxonase, and concentrations of albumin, total bilirubin, total plasma reactive oxygen species (ROS), ferric reducing ability of plasma (FRAP), haptoglobin, ceruloplasmin, nitric oxide and nitric oxide metabolites, $\beta$-carotene, retinol, and tocopherol were analyzed as described by Lopreiato et al. (2019).

\section{Adipose Tissue Biopsies}

Cows in HBCS and NBCS averaged $28 \pm 3 \mathrm{~d}$ in the close-up dry period. All (11/group) were free of clinical disorders and had the full set of biopsies. Tissue was harvested from the tail head (alternating between the right and left tail head region) at $-15( \pm 2 \mathrm{~d}), 7$, and $30 \mathrm{~d}$ relative to parturition according to previous procedures from our laboratory (Ji et al., 2012). Upon collection, adipose tissue was immediately placed in screw-capped microcentrifuge tubes, snap-frozen in liquid nitrogen, and preserved at $-80^{\circ} \mathrm{C}$ until further analysis. Health was monitored for $7 \mathrm{~d}$ after surgery, and surgical clips were removed after $7 \mathrm{~d}$ post-biopsy. No antibiotics were administered post-biopsy.

\section{RNA Isolation, cDNA Synthesis and Quantitative PCR}

Total RNA isolation was performed as described in our previous study (Liang et al., 2019). Briefly, total RNA was isolated from $200 \mathrm{mg}$ of adipose tissue using the miRNeasy kit (Qiagen, Hilden, Germany) according to the manufacturer's protocols. The RNA samples were digested with DNaseI and quantification was assessed using a NanoDrop ND-1000 spectrophotometer (Thermo Fisher Scientific, Waltham, MA). The quality of RNA samples was measured using an Agilent 2100 Bioanalyzer (Agilent Technologies, Santa Clara, CA). The quantitative PCR (qPCR) was performed as described by Osorio et al. (2014). The internal controls for adipose tissue were RPS9, GAPDH and ACTB. These internal control genes were previously confirmed as suitable for adipose tissue gene expression analysis (Vailati-Riboni et al., 2015, 2016, 2017). Gene symbols and names, qPCR performance, and primer informa-

Table 1. Ingredient and nutrient composition of diets fed to Holstein cows with prepartum high $(\geq 3.5)$ or normal $(\leq 3.17)$ BCS during the close-up ( $-28 \mathrm{~d}$ to calving) dry period and early lactation (calving to $30 \mathrm{~d}$ )

\begin{tabular}{|c|c|c|}
\hline Item & Close-up & Lactation \\
\hline \multicolumn{3}{|l|}{ Ingredient, $\%$ of DM } \\
\hline Corn silage & 37.45 & 41.18 \\
\hline Ground shelled corn & 11.10 & 23.40 \\
\hline Wheat straw & 21.80 & 2.30 \\
\hline Canola meal & 11.66 & 3.20 \\
\hline Soybean meal & 6.30 & 13.00 \\
\hline Alfalfa hay & - & 8.60 \\
\hline Soychlor $^{1}$ & 3.37 & - \\
\hline Corn gluten & 2.80 & 2.50 \\
\hline ProvAAL2 AADvantage $^{2}$ & 0.47 & 0.72 \\
\hline Biotin $^{3}$ & 0.10 & 0.08 \\
\hline Rumensin ${ }^{4}$ & 0.19 & 0.02 \\
\hline Calcium sulfate & 0.53 & 0.12 \\
\hline Magnesium oxide & 0.10 & 0.12 \\
\hline $\mathrm{Ca}$ & 0.66 & 1.00 \\
\hline $\mathrm{P}$ & 0.33 & 0.35 \\
\hline Salt & 0.10 & 0.25 \\
\hline $\mathrm{Na}$ & 0.12 & 0.45 \\
\hline $\mathrm{Cl}$ & 0.78 & 0.68 \\
\hline $\mathrm{Mg}$ & 0.45 & 0.38 \\
\hline $\mathrm{K}$ & 1.36 & 1.45 \\
\hline $\mathrm{S}$ & 0.33 & 0.20 \\
\hline \multicolumn{3}{|l|}{ Nutrient composition } \\
\hline $\mathrm{CP}, \%$ of $\mathrm{DM}$ & 14.50 & 17.00 \\
\hline NDF, $\%$ of DM & 43.30 & 21.50 \\
\hline $\mathrm{ADF}, \%$ of $\mathrm{DM}$ & 33.80 & 16.76 \\
\hline aNDFom ${ }^{5} \%$ of DM & 49.21 & 27.01 \\
\hline NFC, $\%$ of DM & 28.22 & 46.83 \\
\hline $\mathrm{NE}_{\mathrm{L}}, \mathrm{Mcal} / \mathrm{kg}$ of $\mathrm{DM}$ & 1.37 & 1.65 \\
\hline $\mathrm{NE}_{\mathrm{L}}$ allowable milk, $\mathrm{kg} / \mathrm{d}$ & - & 25.85 \\
\hline MP allowable milk, kg/d & - & 28.66 \\
\hline RDP, $\%$ of DM & 8.45 & 11.00 \\
\hline RUP, \% of DM & 6.05 & 6.00 \\
\hline RDP required, $\mathrm{g} / \mathrm{d}$ & 1,165 & 1,873 \\
\hline RDP supplied, g/d & 1,152 & 1,995 \\
\hline RDP balance, g/d & -18 & 122 \\
\hline RUP required, g/ & 158 & 1,510 \\
\hline RUP supplied, g/d & 821 & 1,088 \\
\hline RUP balance, g/d & 662 & -421 \\
\hline $\mathrm{MP}$ required, g/d & 821 & 2,404 \\
\hline MP supplied, g/d & 1,360 & 2,041 \\
\hline MP balance, $\mathrm{g} / \mathrm{d}$ & 539 & -362 \\
\hline
\end{tabular}

${ }^{1}$ Anionic supplement; West Central Soy (Ralston, IA).

${ }^{2}$ Rumen-protected methionine; Perdue AgriBusiness (Salisbury, MD). ${ }^{3}$ ADM Animal Nutrition (Quincy, IL).

${ }^{4}$ Monensin ionophore; Elanco Animal Health (Greenfield, IN). ${ }^{5}$ aNDFom $=$ neutral detergent fiber after amylase treatment and ashing. 
tion are reported in Supplemental Table S1 (https:// doi.org/10.3168/jds.2019-17813).

\section{Western Blot Analysis}

Total protein was extracted from $100 \mathrm{mg}$ of adipose tissue using a tissue protein extraction reagent (catalog no. 78510; Thermo Fisher Scientific) containing a Halt protease and phosphatase inhibitor cocktail (100×, catalog no. 78442; Thermo Fisher Scientific). The concentration of total protein was determined using a Pierce bicinchoninic acid protein assay kit (catalog no. 23227; Thermo Fisher Scientific). Details of Western blot were reported in a previous study from our group (Liang et al., 2019). Briefly, protein samples were denatured by heating at $95^{\circ} \mathrm{C}$ for $5 \mathrm{~min}$ before loading 10 $\mu \mathrm{L}$ of protein into each lane of a 4-20\% SDS-PAGE gel (catalog no. 4561096; Bio-Rad, Hercules, CA). Reactions were run for $10 \mathrm{~min}$ at $180 \mathrm{~V}$, and then for 45 to $60 \mathrm{~min}$ at $110 \mathrm{~V}$. Then the protein sample was transferred to the membrane in a Trans-Blot SD Semi-Dry Electrophoretic Transfer Cell (catalog no. 170-3940, Bio-Rad). Membranes were blocked in $1 \times$ Tris-buffered saline (TBST) containing 5\% nonfat milk for $2 \mathrm{~h}$ at room temperature. The membranes were incubated in TBST containing primary antibodies to glutathione Stransferase mu 1 (GSTM1), kelch-like ECH associated protein, extracellular signal-regulated protein kinases 1 and 2, phospho-extracellular signal-regulated protein kinases 1 and 2(Thr202/Tyr204), NFE2L2 and phospho-NFE2L2(Ser40) (catalog \# and dilution ratio are included in Supplemental Table S2, https://doi.org/10 $.3168 /$ jds.2019-17813) overnight at $4^{\circ} \mathrm{C}$. The membranes were then washed with $1 \times$ TBST and incubated with anti-rabbit horseradish peroxidase (HRP)-conjugated secondary antibodies (catalog no. 7074S; Cell Signaling Technology, dilution 1:1,000). Subsequently, the membranes were washed with $1 \times$ TBST and then incubated with ECL reagent (catalog no. 170-5060; Bio-Rad) before image acquisition. $\beta$-Actin (catalog no. 4967S; Cell Signaling Technology, Danvers, MA) was used as the internal control. Images were acquired using the ChemiDOC MP Imaging System (Bio-Rad). The intensities of the bands were measured with Image-Pro Plus 6.0 software. Specific target protein band density values were normalized to $\beta$-actin density values. Representative blots are included in Supplemental Figure S1 (https://doi.org/10.3168/jds.2019-17813).

\section{Biomarker Analysis in Subcutaneous Adipose Tissue}

As in our previous study (Liang et al., 2019), the following OS biomarkers in SAT were determined using

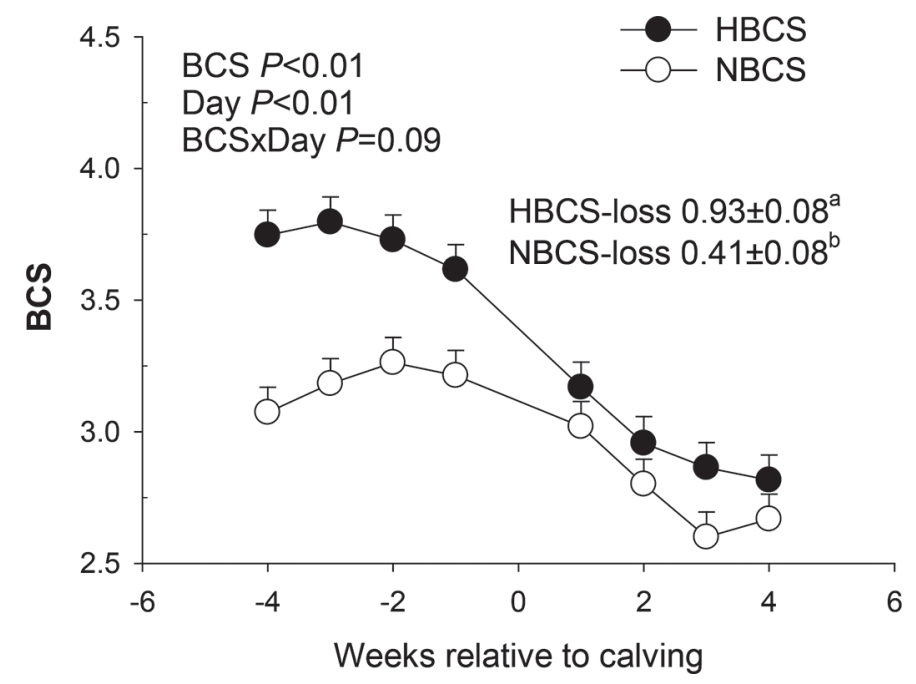

Figure 1. Change in BCS and BCS loss between -4 and 4 wk relative to parturition in Holstein cows with prepartum (28 d before expected parturition) high (HBCS, BCS $\geq 3.5$ ) or normal BCS (NBCS, $\mathrm{BCS} \leq 3.17)$. Data are $\mathrm{LSM} \pm$ pooled SEM, $\mathrm{n}=11$ cows per group. ${ }^{\mathrm{a}, \mathrm{b}}$ Means groups differ $(P \leq 0.05)$.

commercial kits according to manufacturer's instructions: ROS (catalog no. STA-347, Cell Biolabs, San Diego, CA), malondialdehyde (catalog no. 10009055; Cayman Chemical), and GSH (catalog no. NWKGSH01; Northwest Life Science Specialties, Vancouver, WA). Adipose tissue total protein concentration was measured using the Pierce BCA assay kit (catalog no. 23227; Thermo Scientific).

\section{Statistical Analysis}

The data were analyzed using the MIXED procedure of SAS v.9.4 (SAS Institute Inc., Cary, NC) according to the following model with repeated measures:

$$
\mathrm{Y}_{\mathrm{j} 1}=\mu+\mathrm{M}_{\mathrm{j}}+\mathrm{T}_{\mathrm{l}}+\mathrm{MT}_{\mathrm{jl}}+\mathrm{e}_{\mathrm{j} 1}
$$

where $Y_{j 1}=$ dependent, continuous variable, $\mu=$ overall mean, $\mathrm{M}_{\mathrm{j}}=$ fixed effect of $\mathrm{BCS}(\mathrm{j}=\mathrm{HBCS}$ vs. NBCS), $\mathrm{T}_{1}=$ fixed effect of day (for blood biomarkers, $-10,7,15$, and $30 \mathrm{~d}$; for $\mathrm{qPCR}$, Western blot, and OS biomarker in SAT analysis, -15, 7, and $30 \mathrm{~d}$ ), $\mathrm{MT}_{\mathrm{jl}}=$ interaction between BCS and Day, and $\mathrm{e}_{\mathrm{j} 1}=$ residual error. Cow, nested within BCS, was the random effect. The Kenward-Roger statement was used for computing the denominator degrees of freedom. The covariance structure of the repeated measurements was spatial power $[\mathrm{SP}(\mathrm{POW})]$. When the interaction was significant, least squares means separation between and within time points was performed using the PDIFF statement with Tukey adjustment. Normality of the 

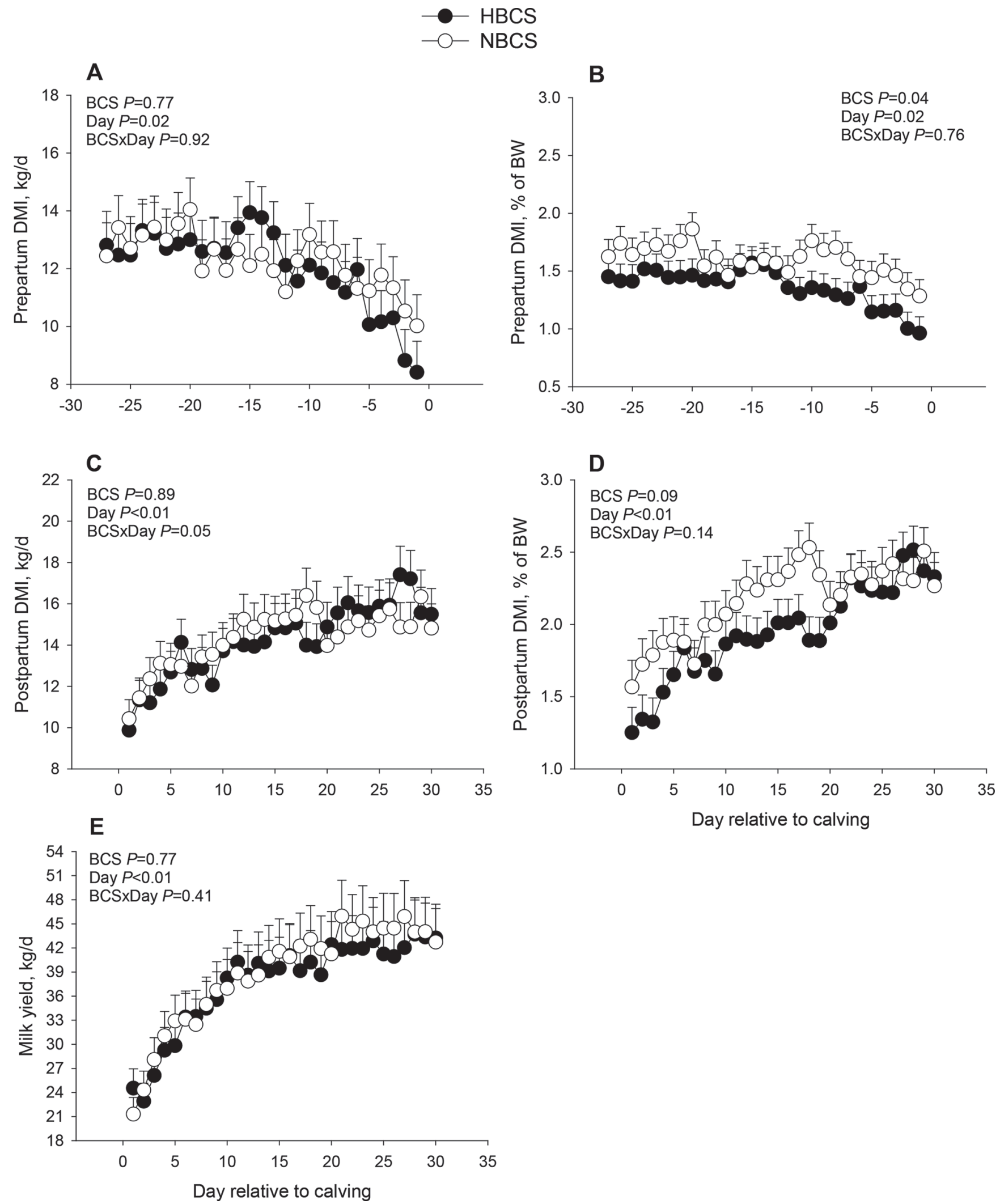

Figure 2. Prepartum and postpartum DMI, DMI as \% of BW, and milk yield of Holstein cows with prepartum (28 d before expected parturition) high (HBCS, BCS $\geq 3.5$ ) or normal BCS (NBCS, BCS $\leq 3.17)-30$ to $30 \mathrm{~d}$ relative to parturition. Data are LSM \pm pooled SEM, $\mathrm{n}=$ 11 cows per group. 
Table 2. Least squares means $(\mathrm{n}=11) \pm$ pooled SEM for plasma biomarkers of inflammation and oxidative stress in Holstein cows with prepartum high or normal BCS

\begin{tabular}{|c|c|c|c|c|c|c|}
\hline \multirow[b]{2}{*}{ Item $^{1}$} & \multicolumn{2}{|c|}{ Group $^{2}$} & \multirow[b]{2}{*}{ SEM } & \multicolumn{3}{|c|}{$P$-value } \\
\hline & HBCS & NBCS & & $\mathrm{BCS}$ & Day & BCS $\times$ Day \\
\hline \multicolumn{7}{|l|}{ Inflammation } \\
\hline Albumin, $\mathrm{g} / \mathrm{L}$ & 36.4 & 35.3 & 0.59 & 0.22 & 0.40 & 0.42 \\
\hline Ceruloplasmin, $\mu \mathrm{mol} / \mathrm{L}$ & 3.21 & 3.11 & 0.14 & 0.59 & $<0.01$ & 0.10 \\
\hline Haptoglobin, g/L & 0.35 & 0.35 & 0.03 & 0.92 & $<0.01$ & 0.68 \\
\hline Myeloperoxidase, U/L & 526 & 518 & 15.2 & 0.71 & 0.01 & 0.63 \\
\hline \multicolumn{7}{|l|}{ Oxidative stress } \\
\hline $\mathrm{FRAP}, \mu \mathrm{mol} / \mathrm{L}$ & 123 & 120 & 3.99 & 0.66 & $<0.01$ & 0.02 \\
\hline $\mathrm{ROS}, \mathrm{H}_{2} \mathrm{O}_{2} / 100 \mathrm{~mL}$ & 16.0 & 15.2 & 0.50 & 0.28 & $<0.01$ & 0.06 \\
\hline $\mathrm{NO}, \mu \mathrm{mol} / \mathrm{L}$ & 26.3 & 26.4 & 0.33 & 0.74 & $<0.01$ & 0.55 \\
\hline Nitrite, $\mu \mathrm{mol} / \mathrm{L}$ & 3.86 & 3.57 & 0.21 & 0.31 & $<0.01$ & 0.26 \\
\hline Nitrate, $\mu \mathrm{mol} / \mathrm{L}$ & 21.9 & 22.5 & 0.35 & 0.23 & $<0.01$ & 0.92 \\
\hline$\beta$-Carotene, mg/100 mL & 0.17 & 0.23 & 0.02 & 0.08 & $<0.01$ & 0.29 \\
\hline Retinol, $\mu \mathrm{g} / \mathrm{mL}$ & 24.9 & 26.5 & 2.01 & 0.58 & $<0.01$ & 0.64 \\
\hline Tocopherol, $\mu \mathrm{g} / \mathrm{mL}$ & 2.85 & 3.18 & 0.18 & 0.21 & $<0.01$ & 0.96 \\
\hline \multicolumn{7}{|l|}{ Liver function } \\
\hline Alkaline phosphatase, U/L & 43.9 & 52.8 & 4.42 & 0.13 & 0.22 & 0.04 \\
\hline AST, U/L & 102 & 103 & 5.85 & 0.96 & $<0.01$ & 0.20 \\
\hline GGT, U/L & 23.5 & 20.6 & 1.58 & 0.18 & $<0.01$ & 0.26 \\
\hline Paraoxonase, U/L & 74.1 & 69.9 & 4.06 & 0.47 & $<0.01$ & 0.44 \\
\hline Bilirubin, $\mu \mathrm{mol} / \mathrm{L}$ & 5.03 & 4.06 & 0.49 & 0.13 & $<0.01$ & 0.22 \\
\hline
\end{tabular}

${ }^{1} \mathrm{FRAP}=$ ferric-reducing ability of plasma; $\mathrm{ROS}=$ reactive oxygen species; $\mathrm{AST}=$ aspartate aminotransferase; GGT $=\gamma$-glutamyl transpeptidase.

${ }^{2} \mathrm{HBCS}=$ high $\mathrm{BCS}(\geq 3.5) ; \mathrm{NBCS}=$ normal BCS $(\leq 3.17)$.

residuals was checked with normal probability and box plots, and homogeneity of variances was checked with plots of residuals versus predicted values. Outliers were removed when the absolute value of studentized residual was $>2$. Significance was declared at $P \leq 0.05$ and tendencies at $P \leq 0.10$.

\section{RESULTS AND DISCUSSION}

\section{Body Condition and Animal Performance}

High BCS cows had greater BCS compared with NBCS cows from -4 to 4 wk relative to calving date $(P<0.01$; Figure 1). Additionally, HBCS cows had greater BCS loss than NBCS cows $(P<0.05$; Figure 1 ). Both prepartum and postpartum DMI did not differ between HBCS and NBCS cows $(P=0.77$ and $P=$ 0.89; Figure $2 \mathrm{~A}$ and $\mathrm{C}$ ), which is in line with Alharthi et al. (2018) and Pires et al. (2013). However, when expressed as percent of BW, NBCS cows had greater prepartum DMI $(P=0.04$; Figure $2 \mathrm{~B})$, and tended to have greater postpartum DMI $(P=0.09$; Figure 2D). Feed intake and milk yield might play a role in regulating BCS when cows are fed and managed under the same conditions (Rocco and McNamara, 2013). Due to the lack of difference in actual amounts of DMI and milk yield $(P=0.77$; Figure $2 \mathrm{E})$, DMI as $\%$ of $\mathrm{BW}$ seems to be a more reasonable indicator of BCS effect on performance.

\section{Blood Parameters Associated with Inflammation and Oxidative Stress}

Compared with the prepartum, plasma ceruloplasmin and haptoglobin concentrations increased after parturition in both HBCS and NBCS cows (Day, $P<0.01$; Table 2, Figure 3A and B). However, ceruloplasmin tended to decrease from 7 to $30 \mathrm{~d}$ postpartum in NBCS cows, whereas HBCS cows showed the opposite trend $(\mathrm{BCS} \times$ Day, $P=0.10$; Figure $3 \mathrm{~A})$. Overall, plasma myeloperoxidase activity increased between -10 and 15 $\mathrm{d}$ around parturition, followed by a sudden decrease at $30 \mathrm{~d}$ after parturition, irrespective of BCS (Day, $P=$ 0.01; Figure 3C). Regardless of BCS, AST activity and bilirubin concentration (indicators of liver function) were greater after parturition and reached a peak at $\mathrm{d}$ 7 (Day, $P<0.01$; Figure 4B and C). Similarly, GGT increased after parturition, regardless of BCS (Day, $P<0.01$; Figure 4A). Additional results are given in Supplemental Figure S2 (https://doi.org/10.3168/ jds.2019-17813).

Acute-phase proteins (APP), a critical part of the acute-phase response, include positive APP (i.e., increase during inflammation), such as haptoglobin, ceruloplasmin, and serum amyloid-A, and negative APP (i.e., decrease during inflammation), such as albumin, apolipoproteins, retinol-binding protein, and paraoxonase (Trevisi et al., 2013; Loor et al., 2013b). Through its antimicrobial activity, myeloperoxidase is a critical 

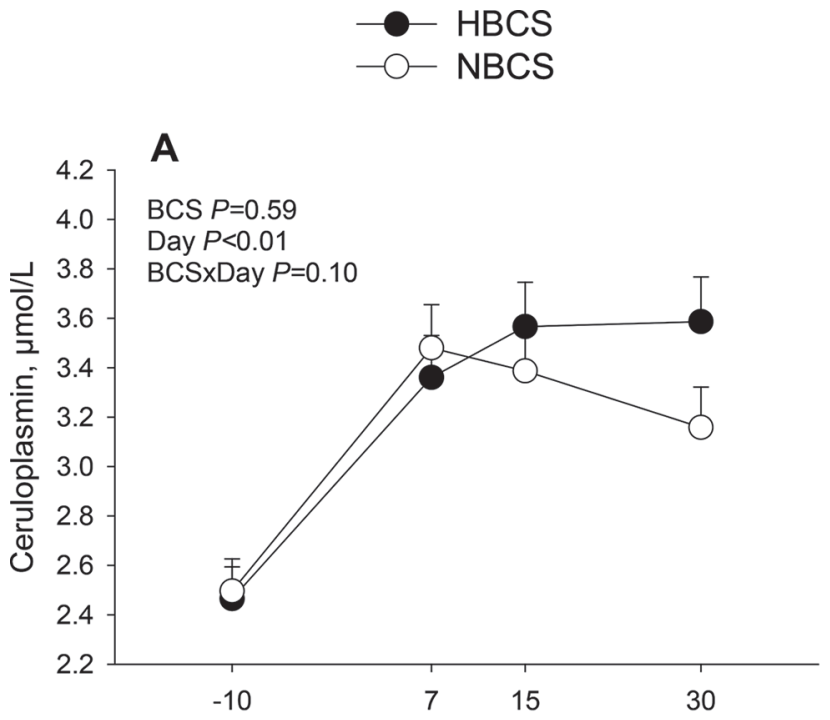

B
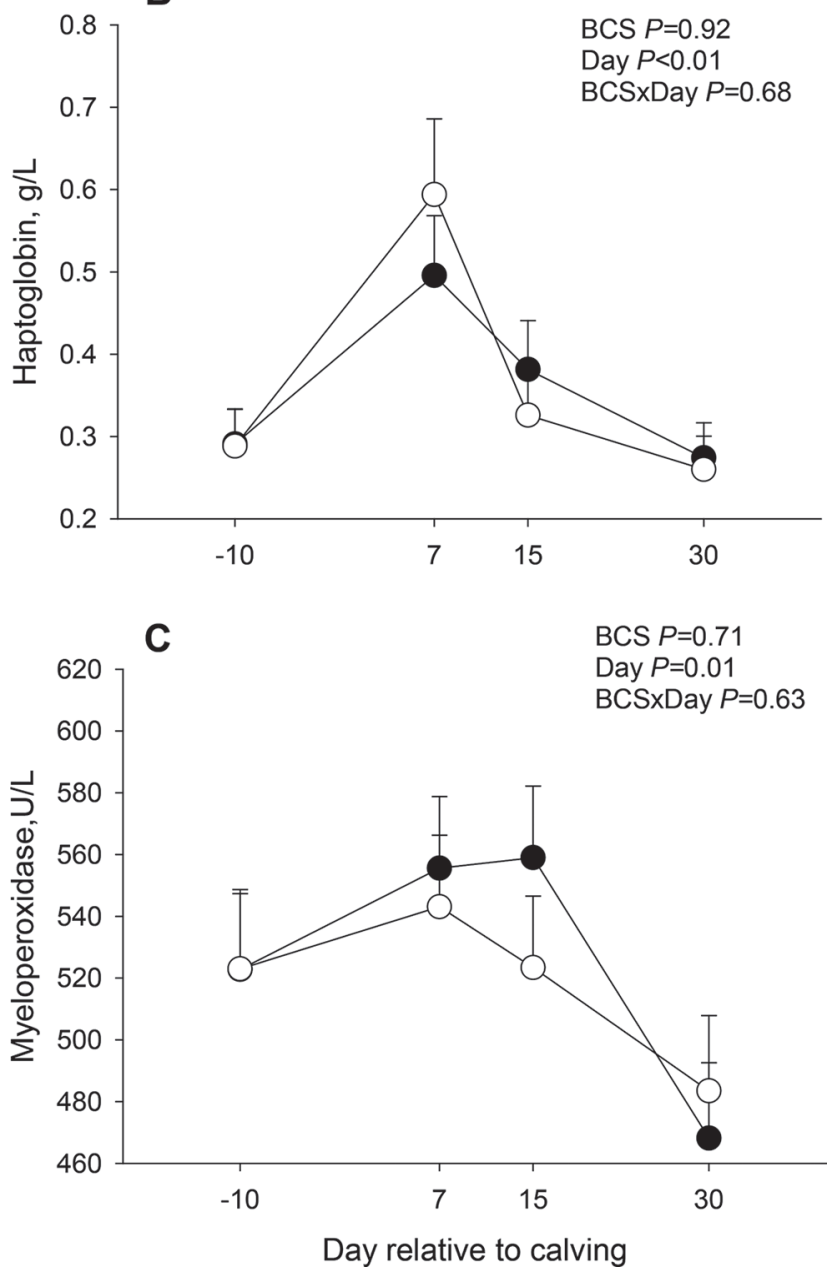

Figure 3. Plasma biomarkers of inflammation in Holstein cows with prepartum ( $28 \mathrm{~d}$ before expected parturition) high (HBCS, BCS $\geq 3.5$ ) or normal BCS (NBCS, BCS $\leq 3.17$ ). (A) Ceruloplasmin; (B) haptoglobin; and (C) myeloperoxidase. Data are LSM \pm pooled SEM, $\mathrm{n}=11$ cows per group.

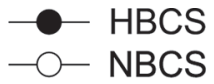

A

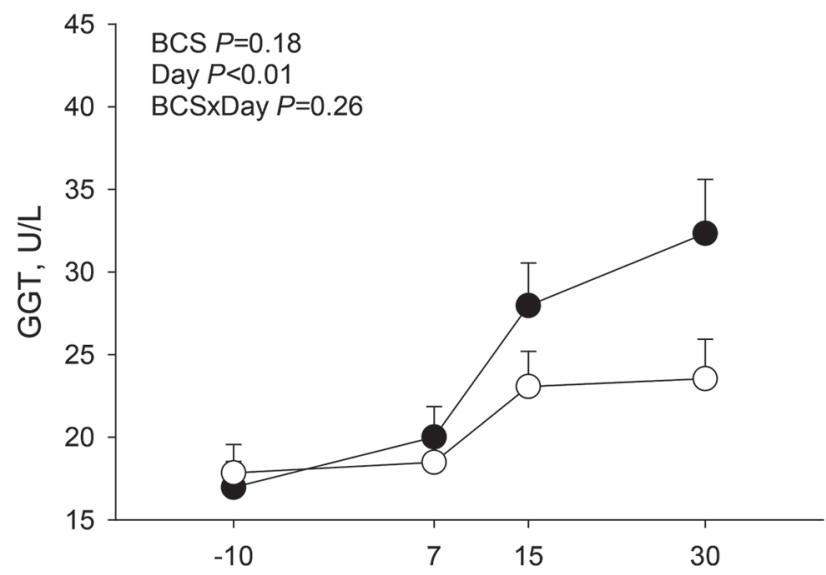

B

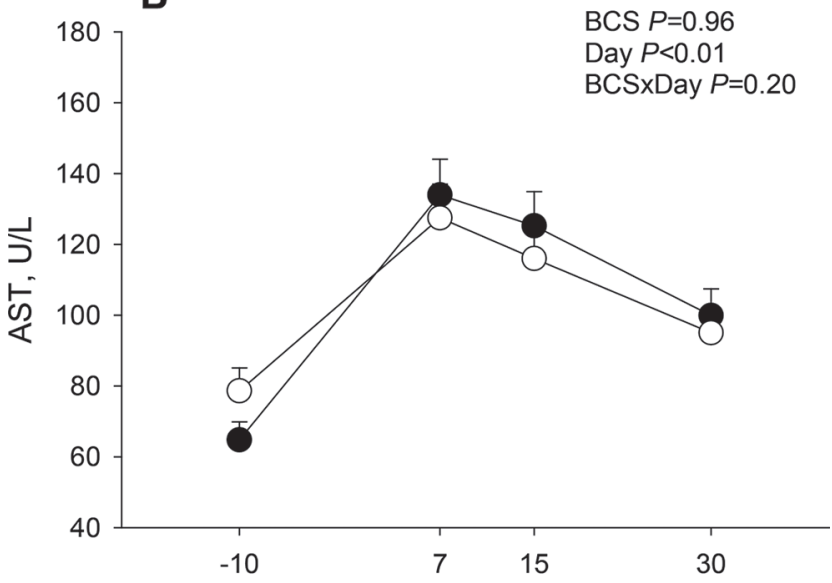

C

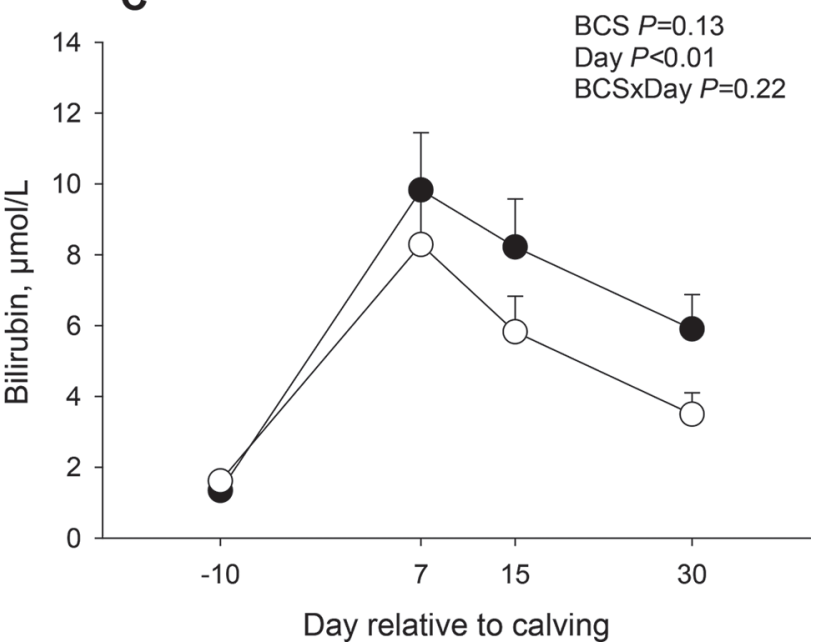

Figure 4. Plasma biomarkers of liver function in Holstein cows with prepartum ( $28 \mathrm{~d}$ before expected parturition) high (HBCS, BCS $\geq 3.5$ ) or normal BCS (NBCS, BCS $\leq 3.17$ ). (A) $\gamma$-Glutamyl transpeptidase (GGT); (B) aspartate aminotransferase (AST); and (C) bilirubin. Data are LSM \pm pooled SEM, $\mathrm{n}=11$ cows per group. 

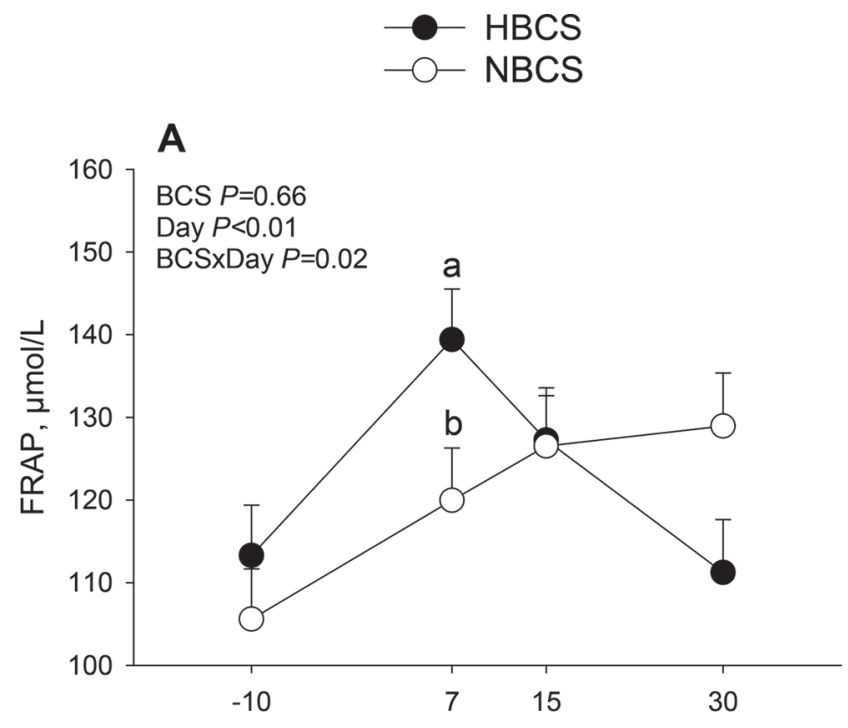

B
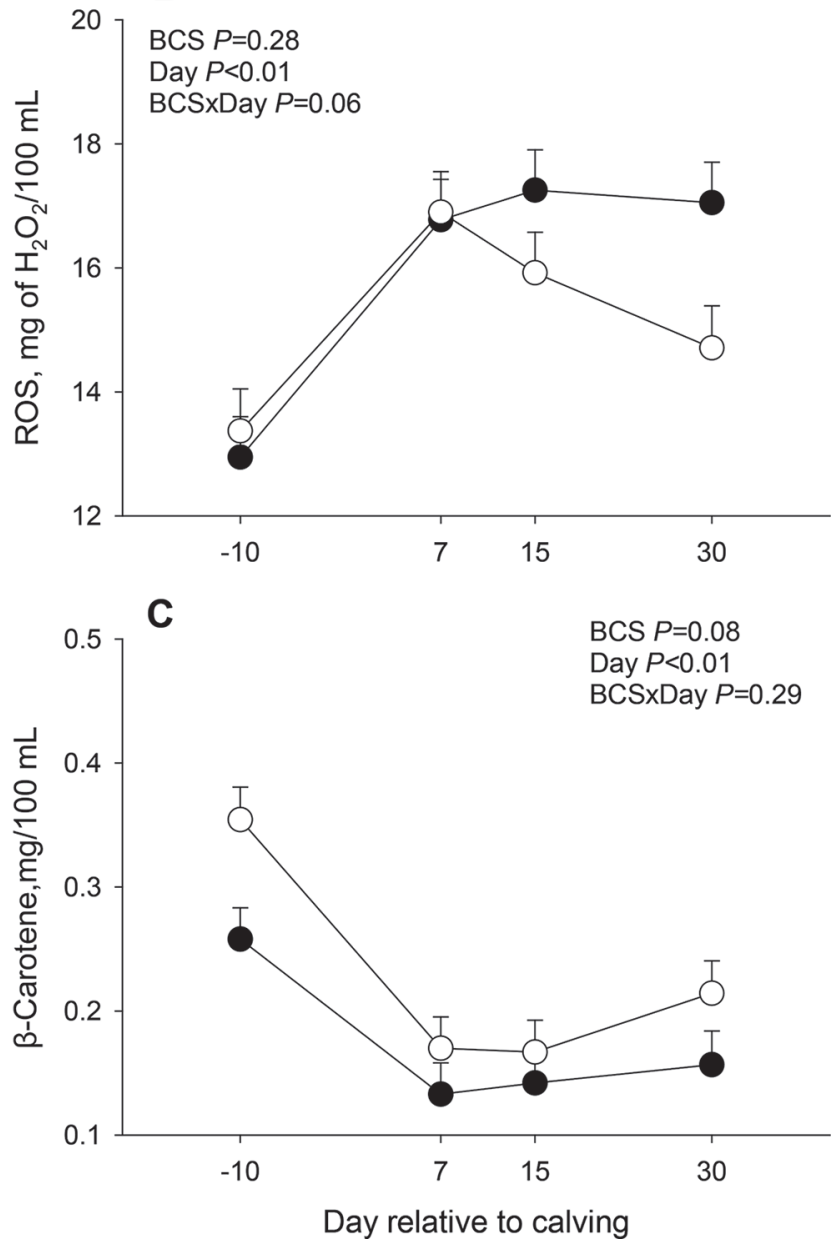

Figure 5. Plasma biomarkers of oxidative stress in Holstein cows with prepartum ( $28 \mathrm{~d}$ before expected parturition) high (HBCS, BCS $\geq 3.5$ ) or normal BCS (NBCS, BCS <3.17) (A) Ferric-reducing ability of plasma (FRAP); (B) reactive oxygen species (ROS); and (C) $\beta$-carotene. Data are LSM \pm pooled SEM, $\mathrm{n}=11$ cows per group. Means with different letters $(\mathrm{a}, \mathrm{b})$ differ $(\mathrm{BCS} \times$ Day, $P \leq 0.05)$. enzyme in regulating innate immunity (Depreester et al., 2017). Changes in the various APP along with markers of liver function are commonly used to study inflammation status of periparturient cows (Bionaz et al., 2007; Bertoni et al., 2008; Graugnard et al., 2013). Increased ceruloplasmin concentration is associated with inflammation (Cerón et al., 2005); thus, its sharp increase after parturition in HBCS and NBCS cows was suggestive of a greater chronic inflammatory response postpartum (Bionaz et al., 2007; Batistel et al., 2018). However, the subsequent decrease in ceruloplasmin in NBCS cows suggested they experienced a shorter inflammatory period (Figure 3A). Although the greater inflammatory status during transition is one adaptive mechanism for dairy cows to cope with acute metabolic changes, a prolonged inflammatory response exacerbates the induction of metabolic disorders (Bertoni et al., 2008). Thus, as reported previously (Treacher et al., 1986; Roche et al., 2009), a prolonged inflammatory response in HBCS cows might contribute to greater susceptibility to metabolic disorders.

The lower concentration of plasma ROS prepartum and increase postpartum (Figure 5B) were in agreement with previous studies (Bernabucci et al., 2005; Batistel et al., 2018). The change in ROS between pre- and postpartum might have been due to the well-known increases in metabolic rate (Reynolds et al., 2003), along with potential direct effects of free fatty acids and BHB on circulating immune cells (Lacetera et al., 2005) or the liver (Sun et al., 2019). Overproduction of ROS results in OS and an ensuing inflammatory response, both of which increase the incidence of metabolic disorders (Bertoni et al., 2008). Thus, we speculate that the relative stability of plasma ROS concentration in HBCS cows after d 7 postpartum (unlike the lower plasma ROS level in NBCS cows) denoted a more prolonged inflammatory state, which agrees with some of the plasma biomarkers analyzed.

The cellular antioxidant $\beta$-carotene is mainly stored in the adipose tissue (Tourniaire et al., 2009), and is the major dietary precursor of vitamin $\mathrm{A}$ in dairy cattle, as well as a precursor for the synthesis of retinoic acid, a metabolite of vitamin A (LeBlanc et al., 2004; Frey and Vogel, 2011). Supplementation with $\beta$-carotene contributes to reduced risk of mastitis and retained placenta, a response associated with its antioxidant properties (Spears and Weiss, 2008). In humans, obesity is associated with lower $\beta$-carotene concentrations in adipocytes (Östh et al., 2014). Although we are unaware if adipose tissue mobilization contributes to the circulating $\beta$-carotene level during the transition period, the fact that all-trans retinoic acid supplementation inhibited inflammation in bovine adipocytes challenged with lipopolysaccharide suggests 
a potentially important indirect effect of this vitamin (Xu et al., 2019). We speculate that maintaining higher concentrations of $\beta$-carotene in the circulation, either through supplementation or optimizing DMI, might directly or indirectly contribute to antioxidant status in SAT during the transition period.

Insulin supplementation in culture medium increased $\beta$-carotene content in bovine adipose explants, whereas epinephrine decreased it, suggesting that hormones related to lipid metabolism influence $\beta$-carotene mobilization from adipose tissue (Arias et al., 2009). However, BCS does not necessarily affect plasma insulin concentrations (e.g., Alharthi et al., 2018). Dairy cows experience increased lipolysis during the transition period, especially after parturition (Loor et al., 2013b). Intense lipolysis is linked to OS and uncontrolled inflammatory responses (Sordillo and Raphael, 2013). In the current study, the postpartal decrease in plasma concentration of $\beta$-carotene, regardless of BCS, was consistent with previous results (Osorio et al., 2014; Batistel et al., 2018). These responses suggest that increased lipolysis, along with OS and enhanced inflammatory response, might contribute to lower levels of circulating $\beta$-carotene. Thus, without differences in DMI, we speculate that HBCS cows are likely to utilize more circulating $\beta$-carotene due to their greater BCS loss. Taken together, the greater overall plasma $\beta$-carotene concentrations in NBCS cows might contribute to their reduced inflammatory response.

Similar to concentrations of ROS, FRAP increased after parturition regardless of BCS, and we detected a BCS $\times$ Day effect $(P<0.01)$ due to a greater response in plasma FRAP on d 7 postpartum in HBCS cows, followed by a decrease until $30 \mathrm{~d}$ postpartum (Figure $5 \mathrm{~A})$. These results are consistent with plasma ROS and $\beta$-carotene data, and support the view that HBCS cows might have experienced greater OS status, especially after parturition (Bernabucci et al., 2005). The effect of lipolysis rate in bovine adipose tissue on $\beta$-carotene metabolism and utilization merits further study.

\section{Oxidative Stress Biomarkers in Adipose Tissue}

Main effects of BCS, Day, and their interaction on OS biomarkers are reported in Table 3, Figure 6, Figure 7, and Figure 8. High BCS cows had lower overall abundance of NFE2L2 $(P=0.03$; Table 3$)$. In rodents, NFE2L2 plays a critical role in the liver in regulating OS via increasing mRNA abundance of key antioxidant enzymes (Ma, 2013). In dairy cows, mRNA abundance of NFE2L2 was first reported in the liver during the periparturient period (Loor, 2010) and recent studies revealed that NFE2L2 is also expressed in the mammary gland and SAT (Zachut et al., 2017; Han et al., 2018b; Liang et al., 2019). In vitro, enhanced activity of NFE2L2 and its target heme oxygenase-1 contributed partly to controlling oxidant status in bovine mammary epithelial cells (Ma et al., 2019).

Overall, the concentration of ROS in SAT was greater in HBCS than NBCS cows $(P<0.01$; Figure $6 \mathrm{~A})$. Free radicals are essential for normal cellular metabolism, but overproduction without sufficient antioxidant capacity often results in DNA and protein damage and apoptosis (Valko et al., 2007). Reactive oxygen species can activate NFE2L2 to protect cells from OS damage (Ray et al., 2012). A recent in vitro study reported that an increase in $\mathrm{H}_{2} \mathrm{O}_{2}$ concentration from 0 to $100 \mu M$ upregulated mRNA abundance of NFE2L2 in bovine adipocytes; however, mRNA abundance of NFE2L2 decreased when the concentration of $\mathrm{H}_{2} \mathrm{O}_{2}$ reached 200

Table 3. Least squares means $(n=11) \pm$ pooled SEM for mRNA abundance of genes related to the NFE2L2 pathway and glutathione metabolism in Holstein cows with prepartum high or normal BCS

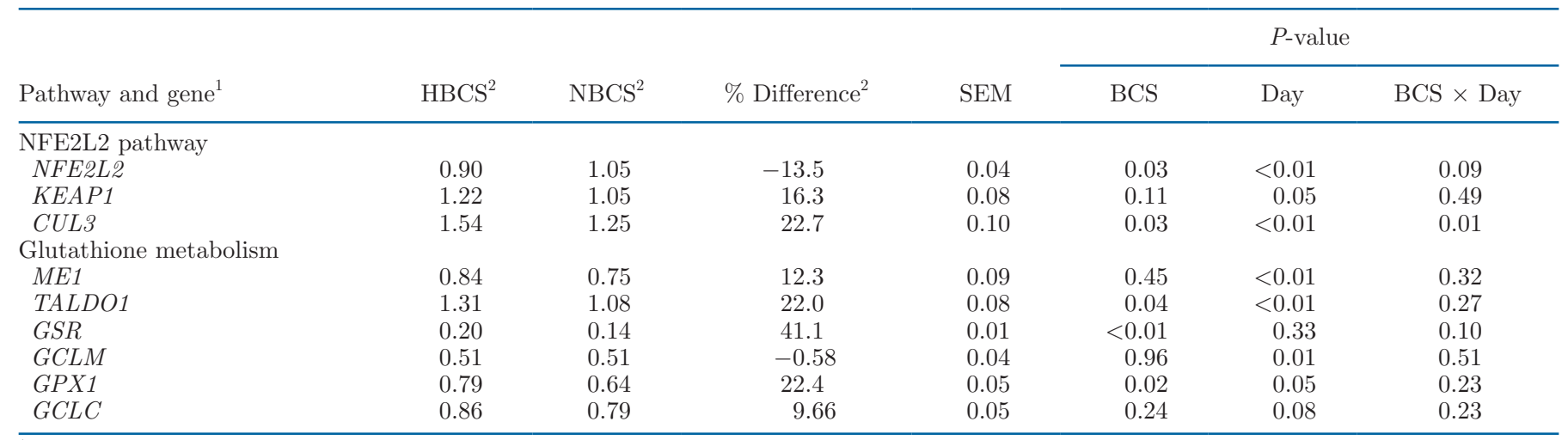

${ }^{1}$ NFE2L2 = nuclear factor, erythroid 2 like $2 ; K E A P 1=$ kelch-like ECH-associated protein $1 ; C U L 3=$ cullin $3 ; M E 1=$ malic enzyme $1 ;$ TALDO1 $=$ transaldolase $1 ; G S R=$ glutathione reductase; $G C L M=$ glutamate-cysteine ligase modifier subunit; GPX1= glutathione peroxidase 1; GCLC $=$ glutamate-cysteine ligase catalytic subunit.

${ }^{2} \mathrm{HBCS}=$ high BCS $(\geq 3.5) ; \mathrm{NBCS}=$ normal BCS $(\leq 3.17) ;$ difference in mRNA abundance $=(\mathrm{HBCS}-\mathrm{NBCS}) / \mathrm{NBCS} \times 100$. 

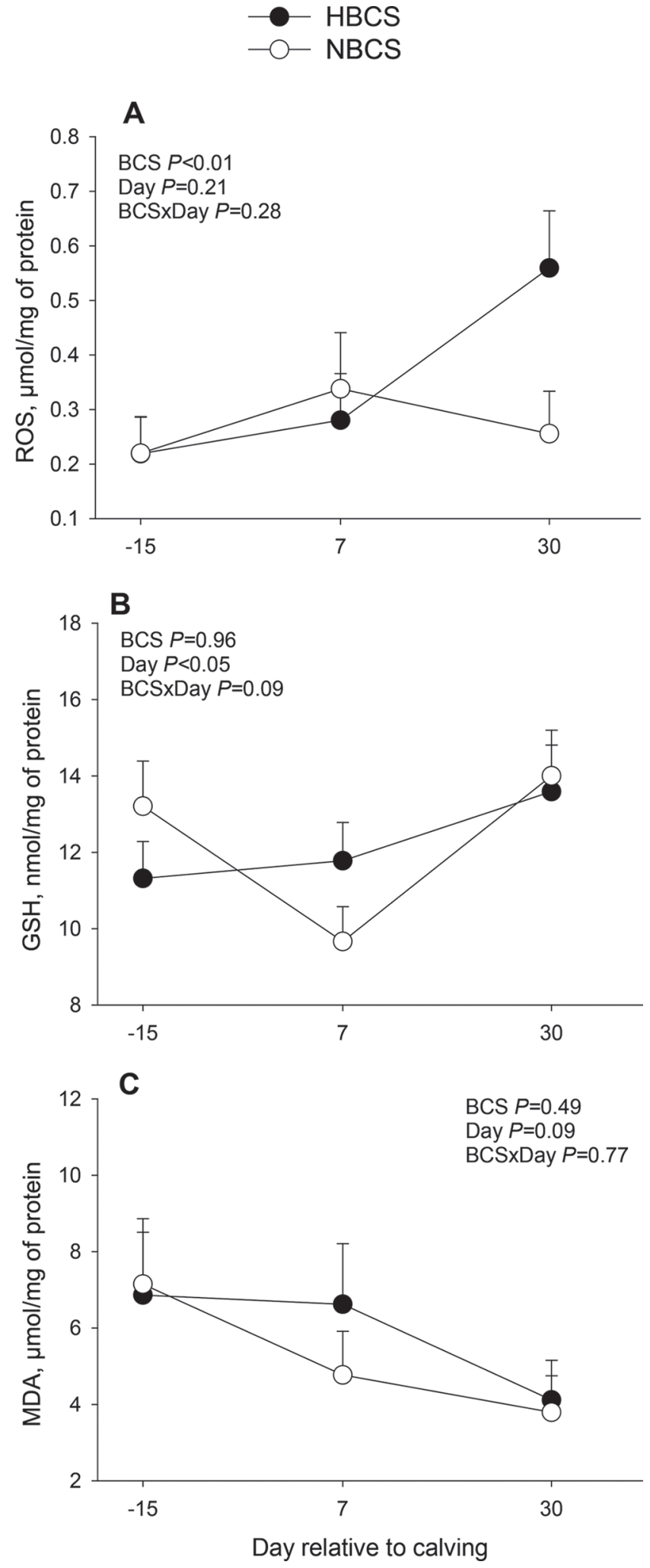

Figure 6. Concentrations in subcutaneous adipose tissue of Holstein cows with prepartum ( $28 \mathrm{~d}$ before expected parturition) high (HBCS, BCS $\geq 3.5$ ) or normal BCS (NBCS, BCS $\leq 3.17$ ). (A) Reactive oxygen species (ROS); (B) glutathione (GSH); and (C) malondialdehyde (MDA). Data are LSM \pm pooled SEM, $\mathrm{n}=11$ cows per group. $\mu M$ (Sun et al., 2019). We speculate that the lower overall abundance of NFE2L2 in HBCS cows (Table 3 ), coupled with greater ROS in SAT, was suggestive of diminished capacity of the tissue to mount an antioxidant response.

Studies in rodents have demonstrated that NFE2L2 function is not only important in regulating OS, but also for adipose development and insulin sensitivity (Schneider and Chan, 2013; Seo and Lee, 2013). The latter is particularly important because periparturient cows experience insulin resistance, especially early postpartum (Holtenius et al., 2003), while recent studies demonstrated that adipose tissue (AT) insulin resistance, especially in over-conditioned cows, develops prepartum (Jaakson et al., 2018). Over-conditioned cows have larger adipocytes in both SAT and omental AT; furthermore, larger adipocytes are more sensitive to lipolytic signals (De Koster et al., 2016). A recent study revealed that BCS loss is positively associated with macrophage infiltration in SAT during early lactation (De Koster et al., 2018). Macrophage infiltration leads to overproduction of ROS and inflammatory cytokines in human and rodent AT (Surmi and Hasty, 2010). In the present study, greater ROS concentration in SAT along with greater BCS loss in HBCS cows led us to speculate that macrophage infiltration might play a role in controlling oxidant status in cows calving at HBCS. The link between NFE2L2 and macrophage infiltration in regulating insulin resistance and adipocyte differentiation as it relates to calving BCS merits further study.

The decrease in plasma ROS after 7 and $15 \mathrm{~d}$ postpartum in NBCS and HBCS cows, respectively (Figure $5 \mathrm{~B}$ ), is noteworthy because ROS concentration in SAT was relatively steady from $-15 \mathrm{~d}$ prepartum to $30 \mathrm{~d}$ postpartum, regardless of BCS (Figure 6A). These data suggest that SAT might take a longer time to recover from OS. Compared with NBCS, HBCS cows had greater overall abundance of cullin 3 (CUL3; $P$ $=0.03$; Table 3). Both KEAP1 and CUL3 are inhibitors of NFE2L2 (Suzuki and Yamamoto, 2017); hence, greater abundance of $C U L 3$ explains at least in part the lower abundance of NFE2L2 in HBCS cows.

In contrast to mRNA abundance, greater overall protein abundance of NFE2L2 and lower phosphorylated (p)-NFE2L2:NFE2L2 ratio was observed in HBCS cows $(P<0.01$ and $P<0.01$; Figure $7 \mathrm{~A}$ and $\mathrm{C})$. The difference between mRNA and protein abundance of NFE2L2 suggests that the activity of NFE2L2 is not regulated at the transcription level. In the present study, there was a BCS $\times$ Day effect for p-NFE2L2 $(P$ $<0.01$ ) due to a decrease in abundance of p-NFE2L2 in HBCS cows, and an increase in NBCS cows from 7 to $30 \mathrm{~d}$ after parturition (Figure 7B). These data provide 
additional support for the idea that OS status increases with time in HBCS cows during the transition period.

\section{Glutathione Metabolism}

Main effects of BCS, Day, and their interaction related to GSH metabolism are reported in Table 3 and Figure 8 . The greater overall abundance of genes associated with GSH metabolism including GXP1, GSR and transaldolase 1 (TALDO1) in HBCS cows $(P=0.02$; $P<0.01 ; P=0.04$; Table 3$)$ was surprising in part because those cows had lower abundance of NFE2L2 $(P=0.03$; Table 3$)$. Cows in HBCS also had greater overall protein abundance of GSTM1 $(P=0.03$; Figure $8 \mathrm{~A})$. Despite these differences at the transcription and translation levels of GSH metabolism components, there was no difference in tissue GSH concentration $(P$ $>0.05$; Figure 6B).

Glutathione is a crucial antioxidant in mammalian cells (Aquilano et al., 2014), and the GSH metabolism pathway is one target regulated by NFE2L2 (Harvey et al., 2009). Although GSH metabolism is closely regulated by OS status in nonruminants (Dickinson and Forman, 2002), other factors such as nuclear factor- $\kappa B$

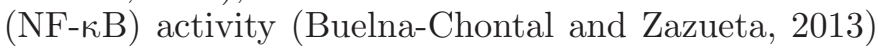
and availability of substrates such as Cys, Gly, and
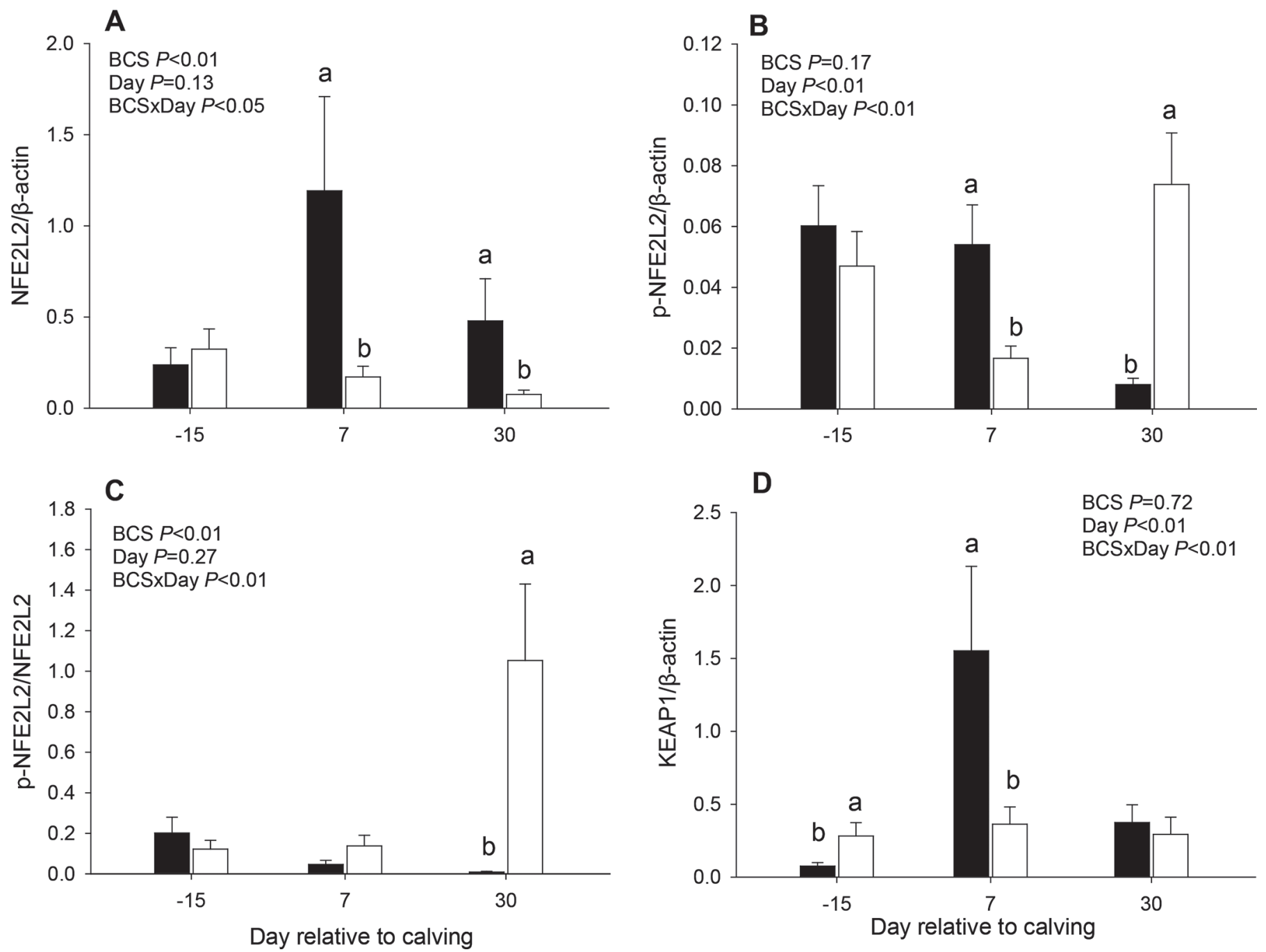

Figure 7. Protein abundance (relative to $\beta$-actin) of the nuclear factor, erythroid 2 like 2 (NFE2L2; inactive, panel A), phosphorylayed (p)-NFE2L2 (active, panel B), ratio of p-NFE2L2/NFE2L2 (panel C), NFE2L2 repressor kelch-like ECH associated protein (KEAP1; panel D) in subcutaneous adipose tissue of Holstein cows with prepartum (28 d before expected parturition) high (HBCS, BCS $\geq 3.5$ ) or normal BCS (NBCS, BCS $\leq 3.17)$. Data are LSM, $\mathrm{n}=11$ cows per group, \pm pooled SEM. Means with different letters $(\mathrm{a}, \mathrm{b})$ differ $(\mathrm{BCS} \times \mathrm{Day}, P \leq 0.05)$. 

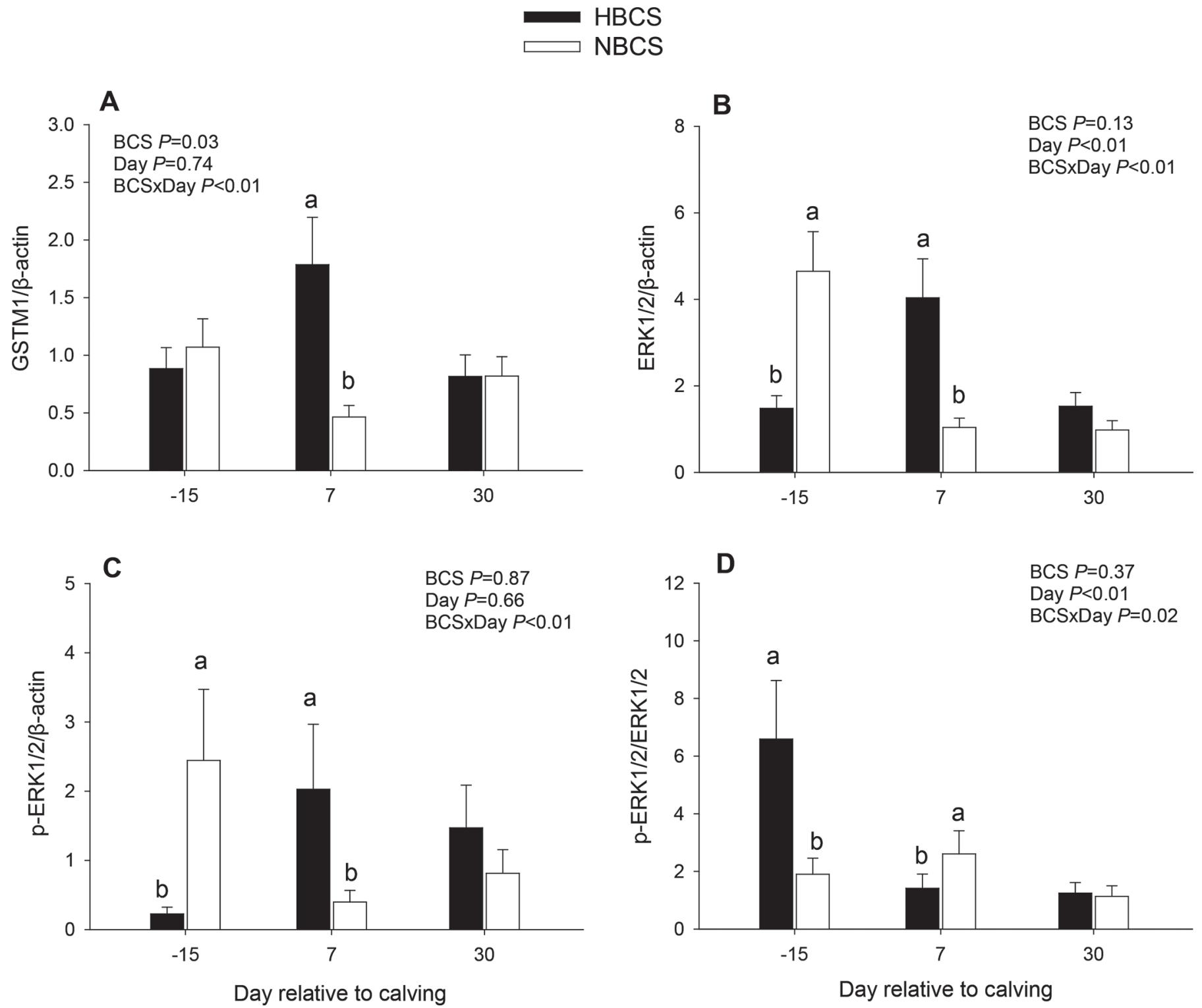

Figure 8. Protein abundance (relative to $\beta$-actin) of the glutathione S-transferase mu 1 (GSTM1; panel A), extracellular signal-regulated protein kinases 1 and 2 (ERK1/2; inactive, panel B), phosphorylated (p)-ERK1/2 (active, panel C), and ratio of p-ERK1/ERK1/2 (panel D) in subcutaneous adipose tissue of Holstein cows with prepartum (28 d before expected parturition) high (HBCS, BCS $\geq 3.5)$ or normal BCS (NBCS, BCS $\leq 3.17)$. Data are LSM \pm pooled SEM, $\mathrm{n}=11$ cows per group. Means with different letters $(\mathrm{a}, \mathrm{b})$ differ $(\mathrm{BCS} \times \mathrm{Day}, P \leq 0.05)$.

Ser affect the pathway (Wu et al., 2004; Lu, 2009). It could be that differences in the rate of mobilization of body protein and differences in DMI to satisfy energy needs determine the availability of AA and other intermediates of the GSH pathway in SAT (Pires et al., 2013; Batistel et al., 2018; Liang et al., 2019). If true, lower availability of AA would lead to decreased mRNA and protein abundance of targets in the GSH metabolism pathway. This idea is partly supported by data from cows fed rumen-protected Met in which a greater DMI was associated with greater mRNA abundance of
GCLM, GSR, and GPX1 in SAT (Liang et al., 2019). Due to the lack of difference in DMI, we speculate that in the present study GSH metabolism was partly regulated by protein mobilization.

Glutathione peroxidases play a crucial role in scavenging and inactivating hydrogen and lipid peroxides in mammalian cells (Cohen and Hochstein, 1963; Drevet, 2006), as well as controlling the inflammatory response (Bozinovski et al., 2012). Thus, it is commonly accepted that greater GPX activity is a positive indicator of health. However, a study in mice demonstrated that 
overexpression of $G P X$ promotes inflammation in lung (Bozinovski et al., 2012). Additionally, decreased GPX activity in mouse adipocytes led to the accumulation of GSH and reduced insulin sensitivity (Kobayashi et al., 2009). Thus, the difference in gene expression of GPX1 between HBCS and NBCS cows might be associated with inflammatory response and insulin resistance in SAT. Although there are no available data in bovine demonstrating a direct link between GSTM1 and oxidative stress in adipose tissue, dairy cows calving in summer exhibited signs of OS, along with lower s.c. abundance of GSTM1 (Zachut et al., 2017). In human lymphocytes, the absence of GSTM1 did not lead to abnormal susceptibility to an oxidant challenge in vitro (Onaran et al., 2001). We speculate that increased mRNA and protein abundance of targets associated with GSH metabolism in SAT were adaptive responses in HBCS cows to counteract the negative effect caused by increased ROS concentration. Overall, these data seem to underscore the need for further studies to better understand the mechanistic role of GSH metabolism in bovine adipose tissue.

\section{CONCLUSIONS}

Although both HBCS and NBCS cows experience OS and inflammation during the periparturient period, these events are likely more pronounced in cows with HBCS, e.g., they had greater overall plasma $\beta$-carotene and ROS concentrations in SAT, especially after parturition. Activation of NFE2L2 in SAT might partly explain the reduced inflammatory response in dairy cows with NBCS. The role of GSH metabolism in bovine adipose tissue merits further study.

\section{ACKNOWLEDGMENTS}

Y. Liang is a recipient of a doctoral fellowship from China Scholarship Council (CSC, Beijing, China). A. S. Alharthi received a fellowship from King Saud University to perform his $\mathrm{PhD}$ studies at the University of Illinois (Urbana). A. A. Elolimy was recipient of a fellowship from Higher Education Ministry, Egypt to perform his Ph.D. studies at the University of Illinois (Urbana). We thank Perdue AgriBusiness (Salisbury, MD) for the donation of ProvAAL2 AADvantage during the course of the experiment. The authors have not stated any conflicts of interest.

\section{REFERENCES}

Alharthi, A., Z. Zhou, V. Lopreiato, E. Trevisi, and J. J. Loor. 2018. Body condition score prior to parturition is associated with plasma and adipose tissue biomarkers of lipid metabolism and inflamma- tion in Holstein cows. J. Anim. Sci. Biotechnol. 9:12. https://doi .org/10.1186/s40104-017-0221-1.

Aquilano, K., S. Baldelli, and M. R. Ciriolo. 2014. Glutathione: New roles in redox signaling for an old antioxidant. Front. Pharmacol. 5:196. https://doi.org/10.3389/fphar.2014.00196.

Arias, E., A. González, A. Shimada, A. Varela-Echavarria, F. RuizLópez, A. During, and O. Mora. 2009. B-Carotene is incorporated or mobilized along with triglycerides in bovine adipose tissue in response to insulin or epinephrine. J. Anim. Physiol. Anim. Nutr. (Berl.) 93:83-93. https://doi.org/10.1111/j.1439-0396.2007.00783 .x.

Batistel, F., J. Arroyo, A. Bellingeri, L. Wang, B. Saremi, C. Parys, E. Trevisi, F. Cardoso, and J. Loor. 2017. Ethyl-cellulose rumenprotected methionine enhances performance during the periparturient period and early lactation in Holstein dairy cows. J. Dairy Sci. 100:7455-7467. https://doi.org/10.3168/jds.2017-12689.

Batistel, F., J. Arroyo, C. Garces, E. Trevisi, C. Parys, M. Ballou, F. Cardoso, and J. Loor. 2018. Ethyl-cellulose rumen-protected methionine alleviates inflammation and oxidative stress and improves neutrophil function during the periparturient period and early lactation in Holstein dairy cows. J. Dairy Sci. 101:480-490. https:// doi.org/10.3168/jds.2017-13185.

Bernabucci, U., B. Ronchi, N. Lacetera, and A. Nardone. 2005. Influence of body condition score on relationships between metabolic status and oxidative stress in periparturient dairy cows. J. Dairy Sci. 88:2017-2026. https://doi.org/10.3168/jds.S0022 -0302(05)72878-2.

Bertoni, G., E. Trevisi, X. Han, and M. Bionaz. 2008. Effects of inflammatory conditions on liver activity in puerperium period and consequences for performance in dairy cows. J. Dairy Sci. 91:33003310. https://doi.org/10.3168/jds.2008-0995.

Bionaz, M., E. Trevisi, L. Calamari, F. Librandi, A. Ferrari, and G. Bertoni. 2007. Plasma paraoxonase, health, inflammatory conditions, and liver function in transition dairy cows. J. Dairy Sci 90:1740-1750. https://doi.org/10.3168/jds.2006-445.

Bozinovski, S., H. J. Seow, P. J. Crack, G. P. Anderson, and R. Vlahos, 2012. Glutathione peroxidase-1 primes pro-inflammatory cytokine production after LPS challenge in vivo. PLoS One 7:e33172. https: //doi.org/10.1371/journal.pone.0033172.

Buelna-Chontal, M., and C. Zazueta. 2013. Redox activation of Nrf2 \& NF-кB: A double end sword? Cell. Signal. 25:2548-2557. https: //doi.org/10.1016/j.cellsig.2013.08.007.

Cerón, J. J., P. D. Eckersall, and S. Martínez-Subiela. 2005. Acute phase proteins in dogs and cats: current knowledge and future perspectives. Vet. Clin. Pathol. 34:85-99. https://doi.org/10.1111/ j.1939-165X.2005.tb00019.x.

Cohen, G., and P. Hochstein. 1963. Glutathione peroxidase: the primary agent for the elimination of hydrogen peroxide in erythrocytes. Biochemistry. 2:1420-1428. https://doi.org/10.1021/bi00906a038.

De Koster, J., M. Hostens, M. Van Eetvelde, K. Hermans, S. Moerman, H. Bogaert, E. Depreester, W. Van den Broeck, and G. Opsomer. 2015. Insulin response of the glucose and fatty acid metabolism in dry dairy cows across a range of body condition scores. J. Dairy Sci. 98:4580-4592. https://doi.org/10.3168/jds.2015-9341.

De Koster, J., C. Strieder-Barboza, J. de Souza, A. L. Lock, and G. A. Contreras. 2018. Short communication: Effects of body fat mobilization on macrophage infiltration in adipose tissue of early lactation dairy cows. J. Dairy Sci. 101:7608-7613. https://doi.org/10 $.3168 /$ jds.2017-14318.

De Koster, J., W. Van den Broeck, L. Hulpio, E. Claeys, M. Van Eetvelde, K. Hermans, M. Hostens, V. Fievez, and G. Opsomer. 2016. Influence of adipocyte size and adipose depot on the in vitro lipolytic activity and insulin sensitivity of adipose tissue in dairy cows at the end of the dry period. J. Dairy Sci. 99:2319-2328. https:// doi.org/10.3168/jds.2015-10440.

Depreester, E., J. De Koster, M. Van Poucke, M. Hostens, W. Van den Broeck, L. Peelman, G. A. Contreras, and G. Opsomer. 2018. Influence of adipocyte size and adipose depot on the number of adipose tissue macrophages and the expression of adipokines in dairy cows at the end of pregnancy. J. Dairy Sci. 101:6542-6555. https://doi.org/10.3168/jds.2017-13777. 
Depreester, E., E. Meyer, K. Demeyere, M. Van Eetvelde, M. Hostens, and G. Opsomer. 2017. Flow cytometric assessment of myeloperoxidase in bovine blood neutrophils and monocytes. J. Dairy Sci. 100:7638-7647. https://doi.org/10.3168/jds.2016-12186.

Dickinson, D. A., and H. J. Forman. 2002. Cellular glutathione and thiols metabolism. Biochem. Pharmacol. 64:1019-1026. https:// doi.org/10.1016/S0006-2952(02)01172-3.

Drevet, J. R. 2006. The antioxidant glutathione peroxidase family and spermatozoa: a complex story. Mol. Cell. Endocrinol. 250:70-79. https://doi.org/10.1016/j.mce.2005.12.027.

Edmonson, A. J., I. J. Lean, L. D. Weaver, T. Farver, and G. Webster. 1989. A body condition scoring chart for Holstein dairy cows. J. Dairy Sci. 72:68-78. https://doi.org/10.3168/jds.S0022 $-0302(89) 79081-0$

Frey, S. K., and S. Vogel. 2011. Vitamin A metabolism and adipose tissue biology. Nutrients 3:27-39. https://doi.org/10.3390/ nu3010027.

Gessner, D. K., G. Schlegel, J. Keller, F. J. Schwarz, R. Ringseis, and K. Eder. 2013. Expression of target genes of nuclear factor E2related factor 2 in the liver of dairy cows in the transition period and at different stages of lactation. J. Dairy Sci. 96:1038-1043. https://doi.org/10.3168/jds.2012-5967.

Graugnard, D. E., K. M. Moyes, E. Trevisi, M. J. Khan, D. Keisler, J. K. Drackley, G. Bertoni, and J. J. Loor. 2013. Liver lipid content and inflammometabolic indices in peripartal dairy cows are altered in response to prepartal energy intake and postpartal intramammary inflammatory challenge. J. Dairy Sci. 96:918-935. https:// doi.org/10.3168/jds.2012-5676.

Han, L., F. Batistel, Y. Ma, A. Alharthi, C. Parys, and J. Loor. 2018a. Methionine supply alters mammary gland antioxidant gene networks via phosphorylation of nuclear factor erythroid 2-like 2 (NFE2L2) protein in dairy cows during the periparturient period. J. Dairy Sci. 101:8505-8512. https://doi.org/10.3168/jds.2017 $-14206$.

Han, L.Q., Z. Zhou, Y. Ma, F. Batistel, J.S. Osorio, and J. J. Loor. 2018b. Phosphorylation of nuclear factor erythroid 2-like 2 (NFE2L2) in mammary tissue of Holstein cows during the periparturient period is associated with mRNA abundance of antioxidant gene networks. J. Dairy Sci. 101:6511-6522. https://doi.org/10 .3168/jds.2017-14257.

Harvey, C. J., R. K. Thimmulappa, A. Singh, D. J. Blake, G. Ling, N. Wakabayashi, J. Fujii, A. Myers, and S. Biswal. 2009. Nrf2regulated glutathione recycling independent of biosynthesis is critical for cell survival during oxidative stress. Free Radic. Biol. Med. 46:443-453. https://doi.org/10.1016/j.freeradbiomed.2008.10.040.

Holtenius, K., S. Agenäs, C. Delavaud, and Y. Chilliard. 2003. Effects of feeding intensity during the dry period. 2. Metabolic and hormonal responses. J. Dairy Sci. 86:883-891. https://doi.org/10 $.3168 /$ jds.S0022-0302(03)73671-6.

Jaakson, H., P. Karis, K. Ling, A. Ilves-Luht, J. Samarütel, M. Henno, I. Jõudu, A. Waldmann, E. Reimann, P. Pärn, R. M. Bruckmaier, J. J. Gross, T. Kaart, M. Kass, and M. Ots. 2018. Adipose tissue insulin receptor and glucose transporter 4 expression, and blood glucose and insulin responses during glucose tolerance tests in transition Holstein cows with different body condition. J. Dairy Sci. 101:752-766. https://doi.org/10.3168/jds.2017-12877.

Ji, P., J. Osorio, J. Drackley, and J. Loor. 2012. Overfeeding a moderate energy diet prepartum does not impair bovine subcutaneous adipose tissue insulin signal transduction and induces marked changes in peripartal gene network expression. J. Dairy Sci. 95:4333-4351. https://doi.org/10.3168/jds.2011-5079.

Kobayashi, H., M. Matsuda, A. Fukuhara, R. Komuro, and I. Shimomura. 2009. Dysregulated glutathione metabolism links to impaired insulin action in adipocytes. Am. J. Physiol. Endocrinol. Metab. 296:E1326-E1334. https://doi.org/10.1152/ajpendo.90921 .2008 .

Lacetera, N., D. Scalia, U. Bernabucci, B. Ronchi, D. Pirazzi, and A. Nardone. 2005. Lymphocyte functions in overconditioned cows around parturition. J. Dairy Sci. 88:2010-2016. https://doi.org/10 $.3168 /$ jds.S0022-0302(05)72877-0.
LeBlanc, S. J., T. H. Herdt, W. M. Seymour, T. F. Duffield, and K. E. Leslie. 2004. Peripartum serum vitamin E, retinol, and betacarotene in dairy cattle and their associations with disease. J. Dairy Sci. 87:609-619. https://doi.org/10.3168/jds.S0022-0302(04)73203 -8 .

Liang, Y., F. Batistel, C. Parys, and J. Loor. 2019. Glutathione metabolism and nuclear factor erythroid 2-like 2 (NFE2L2)-related proteins in adipose tissue are altered by supply of ethyl-cellulose rumen-protected methionine in peripartal Holstein cows. J. Dairy Sci. 102:5530-5541. https://doi.org/10.3168/jds.2018-15687.

Loor, J. J. 2010. Genomics of metabolic adaptations in the peripartal cow. Animal 4:1110-1139. https://doi.org/10.1017/ S1751731110000960.

Loor, J. J., G. Bertoni, A. Hosseini, J. R. Roche, and E. Trevisi. 2013a. Functional welfare - Using biochemical and molecular technologies to understand better the welfare state of peripartal dairy cattle. Anim. Prod. Sci. 53:931-953.

Loor, J. J., M. Bionaz, and J. K. Drackley. 2013b. Systems physiology in dairy cattle: Nutritional genomics and beyond. Annu. Rev. Anim. Biosci. 1:365-392. https://doi.org/10.1146/annurev-animal $-031412-103728$

Lopreiato, V., A. Minuti, F. Trimboli, D. Britti, V. M. Morittu, F. P. Cappelli, J. J. Loor, and E. Trevisi. 2019. Immunometabolic status and productive performance differences between periparturient Simmental and Holstein dairy cows in response to pegbovigrastim. J. Dairy Sci. 102:9312-9327. https://doi.org/10.3168/jds 2019-16323.

Lu, S. C. 2009. Regulation of glutathione synthesis. Mol. Aspects Med. 30:42-59. https://doi.org/10.1016/j.mam.2008.05.005.

Ma, Q. 2013. Role of nrf2 in oxidative stress and toxicity. Annu. Rev. Pharmacol. Toxicol. 53:401-426. https://doi.org/10.1146/annurev -pharmtox-011112-140320.

Ma, Y. F., Z. H. Wu, M. Gao, and J. J. Loor. 2018. Nuclear factor erythroid 2-related factor 2 antioxidant response element pathways protect bovine mammary epithelial cells against $\mathrm{H}_{2} \mathrm{O}_{2}$-induced oxidative damage in vitro. J. Dairy Sci. 101:5329-5344. https://doi .org/10.3168/jds.2017-14128.

Ma, Y. F., L. Zhao, D. N. Coleman, M. Gao, and J. J. Loor. 2019. Tea polyphenols protect bovine mammary epithelial cells from hydrogen peroxide-induced oxidative damage in vitro by activating NFE2L2/HMOX1 pathways. J. Dairy Sci. 102:1658-1670. https:// doi.org/10.3168/jds.2018-15047.

National Research Council. 2001. Nutrient Requirements of Dairy Cattle. 7th rev. ed. Natl. Acad. Press, Washington, DC.

Newman, A. W., A. Miller, F. A. Leal Yepes, E. Bitsko, D. Nydam, and S. Mann. 2019. The effect of the transition period and postpartum body weight loss on macrophage infiltrates in bovine subcutaneous adipose tissue. J. Dairy Sci. 102:1693-1701. https://doi .org/10.3168/jds.2018-15362.

Onaran, İ., G. Güven, A. Ozaydin, and T. Ulutin. 2001. The influence of GSTM1 null genotype on susceptibility to in vitro oxidative stress. Toxicology 157:195-205. https://doi.org/10.1016/S0300 $-483 \mathrm{X}(00) 00358-9$.

Osorio, J. S., P. Ji, J. K. Drackley, D. Luchini, and J. J. Loor. 2014. Smartamine M and MetaSmart supplementation during the peripartal period alter hepatic expression of gene networks in 1-carbon metabolism, inflammation, oxidative stress, and the growth hormone-insulin-like growth factor 1 axis pathways. J. Dairy Sci. 97:7451-7464. https://doi.org/10.3168/jds.2014-8680.

Östh, M., A. Öst, P. Kjolhede, and P. Strålfors. 2014. The concentration of $\beta$-carotene in human adipocytes, but not the whole-body adipocyte stores, is reduced in obesity. PLoS One 9:e85610. https: //doi.org/10.1371/journal.pone.0085610.

Pires, J. A. A., C. Delavaud, Y. Faulconnier, D. Pomiès, and Y. Chilliard. 2013. Effects of body condition score at calving on indicators of fat and protein mobilization of periparturient Holstein-Friesian cows. J. Dairy Sci. 96:6423-6439. https://doi.org/10.3168/jds.2013 $-6801$.

Ray, P. D., B.-W. Huang, and Y. Tsuji. 2012. Reactive oxygen species (ROS) homeostasis and redox regulation in cellular signaling. Cell. Signal. 24:981-990. https://doi.org/10.1016/j.cellsig.2012.01.008. 
Reid, I., C. Roberts, R. Treacher, and L. Williams. 1986. Effect of body condition at calving on tissue mobilization, development of fatty liver and blood chemistry of dairy cows. Anim. Sci. 43:7-15. https://doi.org/10.1017/S0003356100018298.

Reynolds, C. K., P. C. Aikman, B. Lupoli, D. J. Humphries, and D. E. Beever. 2003. Splanchnic metabolism of dairy cows during the transition from late gestation through early lactation. J. Dairy Sci. 86:1201-1217. https://doi.org/10.3168/jds.S0022-0302(03)73704 $-7$.

Rocco, S. M., and J. P. McNamara. 2013. Regulation of bovine adipose tissue metabolism during lactation. 7. Metabolism and gene expression as a function of genetic merit and dietary energy intake. J. Dairy Sci. 96:3108-3119. https://doi.org/10.3168/jds.2012-6097.

Roche, J. R., N. C. Friggens, J. K. Kay, M. W. Fisher, K. J. Stafford, and D. P. Berry. 2009. Invited review: Body condition score and its association with dairy cow productivity, health, and welfare. J. Dairy Sci. 92:5769-5801. https://doi.org/10.3168/jds.2009-2431.

Roche, J. R., J. K. Kay, N. C. Friggens, J. J. Loor, and D. P. Berry. 2013. Assessing and managing body condition score for the prevention of metabolic disease in dairy cows. Vet. Clin. North Am. Food Anim. Pract. 29:323-336. https://doi.org/10.1016/j.cvfa.2013.03 .003 .

Schneider, K. S., and J. Y. Chan. 2013. Emerging role of Nrf2 in adipocytes and adipose biology. Adv. Nutr. 4:62-66. https://doi.org/ 10.3945/an.112.003103.

Seo, H.-A., and I.-K. Lee. 2013. The role of Nrf2: adipocyte differentiation, obesity, and insulin resistance. Oxid. Med. Cell. Longev. 2013:184598. https://doi.org/10.1155/2013/184598.

Sordillo, L. M., and W. Raphael. 2013. Significance of metabolic stress, lipid mobilization, and inflammation on transition cow disorders. Vet. Clin. North Am. Food Anim. Pract. 29:267-278. https://doi .org/10.1016/j.cvfa.2013.03.002.

Spears, J. W., and W. P. Weiss. 2008. Role of antioxidants and trace elements in health and immunity of transition dairy cows. Vet. J. 176:70-76. https://doi.org/10.1016/j.tvjl.2007.12.015.

Sun, X., X. Li, H. Jia, J. J. Loor, R. Bucktrout, Q. Xu, Y. Wang, X. Shu, J. Dong, R. Zuo, L. Yang, G. Liu, and X. Li. 2019. Effect of heat-shock protein B7 on oxidative stress in adipocytes from preruminant calves. J. Dairy Sci. 102:5673-5685. https://doi.org/ $10.3168 /$ jds.2018-15726.

Surmi, B. K., and A. H. Hasty. 2010. The role of chemokines in recruitment of immune cells to the artery wall and adipose tissue. Vascul. Pharmacol. 52:27-36. https://doi.org/10.1016/j.vph.2009.12.004.

Suzuki, T., and M. Yamamoto. 2017. Stress-sensing mechanisms and the physiological roles of the Keap1-Nrf2 system during cellular stress. J. Biol. Chem. 292:16817-16824. https://doi.org/10.1074/ jbc.R117.800169.
Tourniaire, F., E. Gouranton, J. Von Lintig, J. Keijer, M. L. Bonet, J. Amengual, G. Lietz, and J.-F. Landrier. 2009. B-Carotene conversion products and their effects on adipose tissue. Genes Nutr. 4:179-187. https://doi.org/10.1007/s12263-009-0128-3.

Treacher, R., I. Reid, and C. Roberts. 1986. Effect of body condition at calving on the health and performance of dairy cows. Anim. Sci. 43:1-6. https://doi.org/10.1017/S0003356100018286.

Trevisi, E., G. Bertoni, R. Lombardelli, and A. Minuti. 2013. Relation of inflammation and liver function with the plasma cortisol response to adrenocorticotropin in early lactating dairy cows. J. Dairy Sci. 96:5712-5722. https://doi.org/10.3168/jds.2012-6375.

Vailati-Riboni, M., G. Farina, F. Batistel, A. Heiser, M. Mitchell, M. Crookenden, C. Walker, J. Kay, S. Meier, J. Roche, and J. J. Loor. 2017. Far-off and close-up dry matter intake modulate indicators of immunometabolic adaptations to lactation in subcutaneous adipose tissue of pasture-based transition dairy cows. J. Dairy Sci. 100:2334-2350. https://doi.org/10.3168/jds.2016-11790.

Vailati-Riboni, M., M. Kanwal, O. Bulgari, S. Meier, N. Priest, C. Burke, J. Kay, S. McDougall, M. Mitchell, C. Walker, M. Crookenden, A. Heiser, J. R. Roche, and J. J. Loor. 2016. Body condition score and plane of nutrition prepartum affect adipose tissue transcriptome regulators of metabolism and inflammation in grazing dairy cows during the transition period. J. Dairy Sci. 99:758-770. https://doi.org/10.3168/jds.2015-10046.

Vailati Riboni, M., S. Meier, N. Priest, C. Burke, J. Kay, S. McDougall, M. Mitchell, C. Walker, M. Crookenden, A. Heiser, J. R. Roche, and J. J. Loor. 2015. Adipose and liver gene expression profiles in response to treatment with a nonsteroidal antiinflammatory drug after calving in grazing dairy cows. J. Dairy Sci 98:3079-3085. https://doi.org/10.3168/jds.2014-8579.

Valko, M., D. Leibfritz, J. Moncol, M. T. D. Cronin, M. Mazur, and J. Telser. 2007. Free radicals and antioxidants in normal physiological functions and human disease. Int. J. Biochem. Cell Biol. 39:44-84. https://doi.org/10.1016/j.biocel.2006.07.001.

Wu, G., Y.-Z. Fang, S. Yang, J. R. Lupton, and N. D. Turner. 2004. Glutathione metabolism and its implications for health. J. Nutr. 134:489-492. https://doi.org/10.1093/jn/134.3.489.

Xu, Q., H. Jia, L. Ma, G. Liu, C. Xu, Y. Li, X. Li, and X. Li. 2019. Alltrans retinoic acid inhibits lipopolysaccharide-induced inflammatory responses in bovine adipocytes via TGF31/Smad3 signaling pathway. BMC Vet. Res. 15:48. https://doi.org/10.1186/s12917 -019-1791-2.

Zachut, M., G. Kra, L. Livshitz, Y. Portnick, S. Yakoby, G. Friedlander, and Y. Levin. 2017. Seasonal heat stress affects adipose tissue proteome toward enrichment of the Nrf2-mediated oxidative stress response in late-pregnant dairy cows. J. Proteomics 158:52-61. https://doi.org/10.1016/j.jprot.2017.02.011. 